\title{
DOES THE GAAP-SHOE FIT NOT-FOR- PROFIT ORGANISATIONS OR IS IT CAUSING THEM BLISTERS?
}

\author{
Cobus Rossouw \\ University of the Free State \\ rossouj.ekw@ufs.ac.za \\ March 2007
}

\begin{abstract}
Generally Accepted Accounting Practice (GAAP), which comprises International Financial Reporting Standards (IFRSs), has been designed to apply to the general purpose financial statements of all profit-oriented entities, and especially those competing in the international capital markets. On the other hand, not-for-profit organisations exhibit unique characteristics, different from businesses. The nature of not-for-profit organizations means that GAAP (IFRS) is not applicable to them. Small and medium entities (SMEs) and governmental institutions also exhibit unique characteristics and specific accounting standards were developed to meet their specific needs. In South Africa there are no accounting standards that specifically apply to not-for-profit organisations and that take their specific reporting needs into account. This article examines whether GAAP is applicable to not-for-profit organisations, and whether its application adds value to these organisations. The article focuses on the nature of not-for-profit organisations and its impact on accounting standards, discusses the applicability of GAAP and highlights some problems experienced when applying GAAP.
\end{abstract}

\section{Keywords:}

Not-for-profit organisations, Generally Accepted Accounting Practice (GAAP), International Financial Reporting Standards (IFRSs), applicability, accounting, standards, problems. 


\section{INTRODUCTION AND PROBLEM STATEMENT}

Not-for-profit organisations are common in South Africa, where they meet cultural, religious, social, leisure and other needs in society. These organisations have specific accounting needs which have thus far not been addressed by the accounting profession. The danger exists that they are entirely ignored when accounting standards are drawn up, and that standards prepared primarily for businesses are then imposed on them in spite of their non-applicability (compare Leo \& Addison 2000 (a):56-58).

Standards of Generally Accepted Accounting Practice (GAAP) (which represent International Financial Reporting Standards (IFRSs)) have been prepared to assist the users of companies' financial statements, which operate in the international capital markets, to make economic decisions. GAAP is not specifically designed to meet the needs nor to address the unique characteristics of not-for-profit organisations, and the question is posed whether GAAP is applicable to such organisations. GAAP can only add value to these organisations if these standards are indeed applicable and relevant to them.

It would appear that the accounting standards authorities have generally taken the position that not-for-profit organisations do not deserve their attention, understanding or consideration. Given the importance of the not-for-profit sector (compare Swilling and Russel 2002:15-41 and Rossouw 2006:7-9), we have to pose the question whether the financial statements of these organisations, viewed from an accounting perspective, do indeed provide the information required by users so that they may make informed decisions. Negligible research has been conducted thus far on this particular topic (compare Flynne, Leo and Addison 2000:vii).

It is important to note that no specific accounting standard exists in South Africa for notfor-profit organisations, although some specific standards have been issued for these organisations in some countries. As GAAP is the main focal point of accountants and auditors, there is a risk that they will try to apply GAAP in preparing and presenting financial statements for not-for-profit organisations. In doing so, specific problems will be experienced.

The purpose of this article is to highlight the unique characteristics of not-for-profit organisations before considering whether Standards of GAAP are indeed applicable them. In order to achieve the aims of the article, the applicability of Standards for Generally Accepted Accounting Practices (GAAP), which represent International Financial Reporting Standards (IFRSs), is considered from the point of view of a literature study.

The unique characteristics of not-for-profit organisations and the implications of this uniqueness in respect of accounting will be discussed first, after which the development of GAAP will be considered briefly. The focus will then be placed on the applicability of GAAP to not-for-profit organisations. Thereafter some problems experienced in attempts to apply GAAP to not-for-profit organisations will be presented briefly. 


\section{GAAP AND NOT-FOR-PROFIT ORGANISATIONS}

To gain a comprehensive understanding of the relevance of GAAP for not-for-profit organisations, it is necessary briefly to elucidate the nature and characteristics of such organisations, and then to outline the development and nature of "GAAP". These aspects could probably have been couched in a separate research design; however, for the purposes of this article, they are only outlined briefly to serve as a background to the discussion of the relevance of GAAP for not-for-profit organisations.

\subsection{The nature of not-for-profit organisations}

This article will not attempt a single definition of not-for-profit organisations because the activities of these organisations vary considerably. However, the Nonprofit Organisations Act, Act 71 of 1997 (as amended in 2000) (RSA 1997) defines a 'non-profit organisation' as a "... trust, company or other association of persons (a) established for a public purpose; and (b) the income and property of which are not distributable to its members or officebearers except as reasonable compensation for services rendered." For the purposes of this article, we provide the following concise outline of the nature and the characteristics of not-for-profit organisations (compare also Rossouw 2006:20-28).

\subsection{Rationale for the existence of not-for-profit organisations}

Not-for-profit organisations have arisen in response to a need for the social services they provide. They do this without the intention of realising a profit (Kew, Mettler, Walker and Watson 2003:735), and they address the interests of a particular group, and in so doing, are responsive to the cultural, religious, social, leisure and other needs of society (compare Henke 1989:1, and Leo and Addison 2000(a):56-58). The primary focus of a not-for-profit organisation is therefore to render a service intended to address a specific need. These organisations secure the necessary resources from available sources, and then use them to render services or products free or at a low cost (Mautz 1994:8).

\subsection{Profitability and profit-sharing}

It was indicated above that not-for-profit organisations deliver specific services or products, and that they perform these functions primarily without the profit motive; thus, they do not have the intention of showing a surplus from their activities (Durham 1997:82 and Flynne et al. 2000: chapter 1:3). Any surplus income is utilised to extend the rendering of services, and such surpluses are not shared among the "owners" or "equity participants" because they do not actually exist (compare Henke 1988:4-5, Faul, Pistorius, Van Vuuren, Vorster and Myburg 2004:647, and Kew et al. 2003:735, 737).

\subsection{Ownership and control of not-for-profit organisations:}

A distinguishing characteristic of not-for-profit organisations is the fact that there are no owners who, in the case of liquidation, will receive a distribution of funds. Thus, there are no owners who share in "profits" or surpluses (Flynne et al. 2000: chapter 2:6, 14), and for this 
reason, not-for-profit organisations do not have equity shares that can be traded (compare Henke 1988:4-5). These organisations can therefore not be "sold" (Granof 2001:7). Even where they have to be dissolved, the assets must be transferred to another not-for-profit organisation which has similar objectives (compare the Nonprofit Organisations Act, Act 71 of 1997 (as amended in 2000), section 2 (o) (RSA 1997)).

In the case of not-for-profit organisations, individual equity interests do not exist, and control over the organisation is generally located either in persons who have a specific interest in the typical services or products rendered by the organisation, or in persons who have been appointed by members of the organisation or the community. Not-for-profit organisations are therefore controlled by persons who do not have any "investment" in the organisation. Thus, they do not face any risk in the form of personal losses in "investment".

\subsection{Contributions to not-for-profit organisations}

One of the most important characteristics distinguishing not-for-profit organisations from businesses is the fact that persons who contribute to these organisations do so with neither the expectation nor the desire to receive an economic return. Their "decision to give" is therefore in contrast to the "decision to invest" in the case of businesses. For this reason, there is no pressure on these organisations to optimise investors' returns; neither are there "owners" who share in the profits (compare Flynne et al. 2000: chapter 2:6, 7 and chapter $3: 4)$. Not-for-profit organisations source their income from a wide variety of sources such as membership fees, donations, fund-raising projects and government subsidies. These contributions to the funds of not-for-profit organisations do not result in the same rights as would generally been obtained in the case of the contributions of a shareholder to the share capital of a company (for example, the right to receive dividends) (compare Faul et al. 2004:647)

In the section above, a brief outline of the nature and the unique characteristics of notfor-profit organisations was provided, and the implications of these for Accounting are discussed very briefly in the section that follows.

\section{THE IMPLICATIONS OF THE NATURE OF NOT-FOR-PROFIT ORGANISATIONS FOR ACCOUNTING}

It was indicated above that not-for-profit organisations exhibit certain unique characteristics, different from businesses. In essence, the primary objective of not-forprofit organisations is not to realise a profit to be distributed to equity participants (e.g. shareholders), but to meet certain religious, cultural, social and other non-commercial needs of the community. Not-for-profit organisations' need for relevant accounting standards in fact emanates from their unique characteristics.

Owing to the nature of not-for-profit organisations, the users of their financial statements require information (financial and non-financial) which is different from the information required by users of financial statements of businesses. Financial reporting, which makes it possible for the users of financial statements of not-for-profit organisations to assess the stewardship of the organisation's management, is the central focus because management 
are accountable to the members of the organisation (Faul et al. 2004:648), and also especially to donors (Rossouw 2006:51-55).

Henke (1988:7-8) argues that since not-for-profit organisations do not have a pure profit motive, their financial statements must not focus on "profits earned". In spite of the fact that there are no owners for whom profits have to be optimised, the managements of these organisations must still accept responsibility for the effective and efficient utilisation of resources in pursuing the organisation's rationale for existence.

It was also pointed out above that the persons who contribute funds to not-for-profit organisations do not do so as part of an "investment decision". For this reason, aspects of financial reporting which focus on investment decisions and the presentation of information to meet the needs of investors who would like to take informed decisions are therefore less relevant in the case of not-for-profit organisations.

As indicated above, the nature and the characteristics of not-for-profit organisations are clearly different from those of businesses. This aspect is important in the context of this article because it will be indicated below that GAAP was specifically developed for businesses and not for not-for-profit organisations. This implies that GAAP does not take into account the typical nature and the characteristics of these organizations and is therefore irrelevant to them.

\section{THE DEVELOPMENT AND THE NATURE OF “GAAP”}

Accounting is the language that is used to describe the results of economic activities. As the need to use language as a form of communication with other persons increases, the importance of languages will increase (Henke 1988:4). Primitive communities were selfsustaining and did not actually have a need for an Accounting language because there was little reason to keep records of resources, obligations and the processing of resources. As economic activities have escalated, the need arose among buyers and sellers to keep a record of the transactions between them. With the development of specialisation in certain activities, various kinds of business enterprises have evolved where the sources of production and the talents of various persons were joined together. This led to new complications of joint ownership and management of the business enterprise, which in turn required more sophisticated accounting data. The aim of these business enterprises was to realise a profit for their owners (Henke 1988:4).

From an analysis of the history of Accounting, it appears as if the emergence of companies, with the accompanying drawing up of financial statements, may be viewed as the starting point of accounting standards, or GAAP. During the time when individuals engaged in trade in their personal capacity, there was no need to make financial information available to other people. When companies were founded, the owners (or shareholders) were separated from management and from the day-to-day activities of the business entity. Thus, owners were not directly involved in these activities, and they therefore needed information to determine the status of their investment in the company (Vorster, Koornhof, Oberholster and Koppeschaar 2004:1).

As time passed, business transactions became more sophisticated, while the needs of 
stakeholders also increased. For this reason, the accounting rules also increased in number; however, they developed in isolation and at times were in conflict. Later on, it became clear that, as far as possible, a single set of comprehensive and consistent rules for Accounting had to be found. Still later, this led to the development of the standards of GAAP (Vorster et al. 2004:1). From the development of GAAP, it is clear that GAAP developed primarily to serve the needs of users of these companies' financial statements, and not so much to meet the needs of users of not-for-profit organisations' financial statements.

In terms of the Framework (IASB/SAICA 2006-Framework: par. 12-14), the aim of financial statements is to provide information that has a bearing on the financial position, performance and changes in the financial position of an entity. Furthermore, financial statements also provide information on the basis of which the stewardship role of the management of the entity can be assessed. Thus, Accounting is often described as a means of communication (compare Vorster et al. 2004:1 and Sowden-Service 2005:4) because it is the aim of the discipline to provide information to the stakeholders of an entity. Financial reporting is therefore driven by the needs of the users of financial statements (compare Lubbe and Watson 2005:1-3). Accounting is therefore the "language" of the business world, and like any language, it has certain "rules of grammar" so that the "language" may be used consistently, and so that the "listeners" (i.e. the users of financial statements) may understand the language. This "grammar" is known as GAAP (compare Vorster et al. 2004:13, and Sowden-Service 2005:4). The principles on which financial information are drawn up and presented to meet the information needs of users of these financial statements therefore constitute GAAP. Thus, GAAP determines the recognition, measurement and reporting of transactions and events related to an entity (compare Lubbe and Watson 2005:2-3).

According to Granof (2001:22) GAAP represents the rules and regulations which determine the structure and content of general-purpose financial statements. Generally GAAP is indicated by formal documents issued by an official authority (such as the IASB) (compare Vorster et al. 2004:3-4, and Sowden-Service 2005:5-6). In South Africa, GAAP is represented by the Standards for Generally Accepted Accounting Practice (GAAP), which are issued by the South African Institute of Chartered Accountants once the Accounting Practice Board (APB) has approved them (Vorster, et al. 2004:3, and Lubbe and Watson 2005:2-8-11). SA GAAP is a close replica of the International Financial Reporting Standards (IFRSs) as issued by the International Accounting Standards Board (IASB) and is supplemented by unique South African standards, such as, for example, AC 501, which prescribes the accounting treatment of Secondary Tax on Companies (STC). Accounting practices, documented in Standards, are often referred to as "promulgated GAAP" (Vorster, et al. 2004:5).

Granof (2001:22) states the view that GAAP has nonetheless also evolved from the point of view of historical guidelines, and even on the basis of "general practice" that was applied. Many of the "general accounting practices" that were followed have already been included in Standards of GAAP. According to Vorster et al. (2004:3-5), such accounting practices that are "generally accepted", but are nonetheless not codified in Standards, are often referred to as "gaap" (lower-case) or "non-promulgated GAAP". Sowden-Service (2005:8) refers to compliance with "gaap" as "if everyone is doing it, so can we."

Both "GAAP" and "gaap" are indeed accepted and have the same authoritative status, 
although the conclusiveness of "gaap" is far more difficult to achieve (Vorster, et al. 2004:3-5). In terms of Circular 8/99 (SAICA 1999), "gaap" refers to those practices that have achieved general acceptance because they are applied by a significant group, even though they are not stipulated in any Standard of GAAP. It is indeed in this context that not-for-profit organisations, in particular churches and welfare organisations, experience problems with the accounting treatment of transactions because the relevant "gaap" has not yet been documented. These organisations and their auditors have very few documents available for reference purposes to defend and justify their selected accounting practices. Against this background, the applicability and relevance of GAAP for not-for-profit organisations are considered next.

\section{THE APPLICABILITY AND RELEVANCE OF GAAP FOR NOT-FOR-PROFIT ORGANISATIONS}

Not-for-profit organisations have specific accounting needs which have so far not been addressed by the accounting professions. There is a danger that this sector will be overlooked entirely in the process of drawing up accounting standards and that standards prepared primarily for businesses will then be imposed, despite the fact that they are irrelevant to not-for-profit organisations (compare Leo and Addison 2000(a):56-58).

\subsection{The applicability and relevance of GAAP}

In South Africa today, there is no accounting framework or standards that apply specifically to not-for-profit organisations. According to Benjamin-Swales, the chairperson of the South African Public Accountants' and Auditors' Board (PAAB) (currently known as the Independent Regulatory Board for Auditors (IRBA)), and a partner at Ernest [Ernst?] \& Young, this gap poses a significant challenge to the not-for-profit sector (see Temkin in Business Day of 9 November 2004). The large variety of not-for-profit organisational types poses the problem that it is difficult to draw up a uniform accounting framework. According to Agulhas, Director of Auditing Standards at the PAAB, auditors express an opinion on financial statements in terms of an accounting framework. "Without a framework, auditors cannot express an opinion on the available financial information - it is difficult to do so... This is why the non-profit sector is facing so many obstacles... Some cohesion is required" (Temkin in Business Day of 9 November 2004). Furthermore, they indicated that not-forprofit organisations would find it very difficult to apply the new International Financial Reporting Standards (IFRSs) from I January 2005. Agulhas contends that larger and more formal non-governmental organisations "tend to comply with Generally Accepted Accounting Practice, particularly if they receive funding from overseas."

The Preface to the International Financial Reporting Standards (IASB/SAICA 2006 - Preface IFRS:par.9) extends this view, stating that accounting standards have been developed to be applicable to general-purpose financial statements of profit-orientated entities (also compare Sowden-Service 2005:9). According to Lee and Teixeira (2004:21-24), it is a fact that IFRS are drawn up for profit-orientated entities. Furthermore, this Preface also states that, "[a]lthough IFRSs (GAAP) are not designed to apply to not-for-profit activities ..., entities with such activities may find them appropriate" (also compare Cairns 2001:87 and 
Cairns 2002:114). However, there are also parties in Britain who hold the view that the Preface should perhaps be changed to make these standards applicable also to not-forprofit organisations since these organisations are also users of the capital markets, "notably for debt securities" (compare Keegan 2002:17).

The objectives of the International Accounting Standards Board (IASB) with the drawing up of the IFRS constitute yet another aspect which relates to the fact that the Preface states that IFRS (GAAP) is not applicable to not-for-profit organisations. In terms of the Preface (IASB/SAICA 2006 - Preface IFRS:par. 6, 10), the objective of the IASB is to draw up international standards which will lead to the reporting of information in financial statements "... to help participants in the various capital markets of the world and other users of the financial information to make economic decisions ...". The two aspects which are particularly relevant to this article are the "participants in the various capital markets" and "economic decisions". However, not-for-profit organisations participate in capital markets only to a limited extent, and accounting standards that focus on the information needs of participants in international capital markets will probably be irrelevant to notfor-profit organisations (compare Rossouw 2006:32-34, 68). It was already indicated above that the providers of resources to not-for-profit organisations do so for reasons other than recouping economic advantages, and that they do not really take "economic decisions" on the basis of these financial statements, but rather engage in "welfare" or "philanthropic decisions". For this reason, accounting standards that focus on presenting information aimed at assisting in economic decision-making will probably not be entirely relevant to not-for-profit organisations.

According to Ponting (1999:3), National President of the Australian Society of CPAs, accounting and reporting systems which focus on "profit", as in the case of businesses, are of little or no relevance to not-for-profit organisations. When a business shows a loss, there is reason to be concerned; however, this is not necessarily true for not-for-profit organisations. They may merely utilise a year's "retained surplus" to render services to their members that exceeded contributions for that particular year. Ponting furthermore argues that determining profit is particularly irrelevant in reporting on the performance of a welfare organisation since it has come into existence to "give away" everything that it has. Relevant standards for not-for-profit organisations must therefore be found.

The Framework (IASB/SAICA 2006 - Framework: par. 8) stipulates that international standards for financial accounting (IFRS or GAAP) applies to the financial statements of "commercial, industrial and business reporting entities". It is clear that not-for-profit organisations do not fall into any of these categories. Furthermore, the Framework also specifies that a reporting business entity is one where there are users who rely on financial statements as their "major source" of financial information about the entity. For example, in the case of churches and welfare organisations that are dependent on donations and voluntary contributions, it is probable that they will make any financial information available to a person for the purpose of obtaining additional funds and donations. In this case, it is rather the case that the financial statements are perhaps the "first source" of information, rather than the "major source". Given the nature of not-for-profit organisations, their financial statements will probably not report the full performance of the organisation (compare Rossouw 2006:1-4, 69). Standards for GAAP are therefore not technically applicable to not-for-profit organisations. Standards for GAAP's terms of 
reference, measures of recognition and measurement, as well as requirements for disclosure may however have certain aspects in common.

\subsection{Developments of GAAP for specific needs}

The question can be asked whether it is really necessary to have unique accounting principles for not-for-profit organisations. Leo and Addison (2000(b):52-53) refer to an analogy in the business world: they argue that since there are unique principles for certain sectors such as the mining, construction and insurance industries, unique principles should also be defined for not-for-profit organisations. Standards drawn up for businesses cannot be applied indiscriminately to not-for-profit organisations. Leo and Addison pursue this argument, recommending that the next question to be considered is whether a uniform standard should apply to all not-for-profit organisations, or whether there should be standards for various "industries" in the not-for-profit sector. For this purpose, each "industry", such as welfare organisations, universities, religious organisations, etcetera who may hold the view that they require unique principles, will have to argue their case. They recommend that thorough research into the nature and the needs of the not-for-profit sector is required. If the needs of all the different not-for-profit organisations are the same, a single set of rules would be appropriate.

However, Mautz (1994:100-102) proposed long ago that the application of GAAP to not-forprofit organisations should not be abandoned entirely; rather, GAAP had to be applied where the standards applied, and only where they applied. What is further required is to have certain generally accepted accounting principles which prescribe recording and reporting on other unique aspects of not-for-profit organisations' activities. This is the approach which is currently followed for small- and medium-sized entities (as outlined below) and which has already been followed for the public sector and municipal authorities, as indicated next.

The accounting aspects for the public sector (government) and not-for-profit organisations are often mentioned in the same breath (compare, for example, Granof 2001, Wilson and Kattelus 2004, Ives, Razek and Hosch 2004, Engstrom and Copley 2004). In recent years, the so-called GRAP (Generally Recognised Accounting Practice) (ASB 2004(a)) and GAMAP (Generally Accepted Municipal Accounting Practice) (ASB 2004(b)) were developed for the public sector and local authorities (municipalities) respectively. These accounting standards are based primarily on South African Standards for GAAP, but they have been adjusted specifically to provide for the unique circumstances of the public sector and local authorities (RSA 1998). The same approach should probably also be followed for not-forprofit organisations in South Africa.

Non-business organisations (and therefore not-for-profit organisations) do not have to make available the same financial information as businesses to the users of financial statements since the objectives of the two organisational types in providing financial information differ (compare Rossouw 2006:3). Wilson and Kattelus (2004:1-2) also argue that government institutions and not-for-profit organisations require unique accounting practices merely because they serve purposes in the community that are different from those of businesses. Contributors to not-for-profit organisations do not expect yields on their contributions, and for this reason, the managements of not-for-profit organisations 
have a unique accounting responsibility to contributors to ensure that funds are utilised in terms of their intended use. Not-for-profit organisations have unique reporting aspects which have to be understood by the organisations themselves and the users of financial statements (Larkin and DiTommaso 2005:i).

In recent years, there have been many debates, requests and proposals for the so-called "small gaap" or "limited financial reporting" for small- and medium-sized entities. These entities are referred to in accounting jargon as SMEs (small and medium entities) - the term used here as well. Generally, IFRS (which represents SA GAAP) are often described as highly complex and difficult (refer, for example, to Lavigne 1999:49-50 and Paterson 2001:96).

As indicated above, international accounting standards have been developed primarily for reporting entities whose users utilise financial statements as the major source of financial information. These standards also apply to the drawing up of so-called general purpose financial statements intended to provide for the information needs of users who are unable to obtain financial information which they either prefer or require. Furthermore, it is the IASB's objective to set standards which comply with the needs of persons involved in international capital markets (compare Hattingh 2001:35-37). Lavigne (1999:49-50) argues that much of the information required by GAAP has little or no relevance for users of small businesses' financial statements because they are not active in the financial markets.

As indicated above, GAAP is not actually applicable to SMEs merely because of the type of organisation involved, and international attempts are being made to meet these requests on unique standards. The same process will probably apply in the case of not-for-profit organizations, because these organisations, owing to their unique nature, experience unique accounting problems in applying GAAP, as will be outlined in detail below.

According to Kilcullen (2005), lecturer at the Graduate School of Management, University of Western Australia, Australia has accepted the International Financial Reporting Standards (IFRS) with a view to worldwide application from 2005, with minor adjustments. These adjustments were made for the sake of certain administrative requirements of legislation, and guidelines that address specific issues in Australia, as well as guidelines that are given in the Standards for not-for-profit organisations. Specific accounting guidelines that apply to not-for-profit organisations have therefore been inserted in the Australian equivalent of IFRS (also compare Archer 2004:54-55, and AASB 2005). Specific guidelines have been inserted into certain standards, while other standards are not applicable to not-for-profit organisations at all (compare Parker 2003:65-66). Unlike other countries, where only listed companies were required to comply with IFRS, Australian not-for-profit organisations were required to comply with IFRS (or AEIFRS which is the Australian equivalent of IFRS) from 1 January 2005 (compare Archer 2004:54-55).

Since GAAP is not applicable to not-for-profit organisations, as indicated above, it follows that relevant accounting standards for not-for-profit organisations should be drawn up for such organisations. There are "separate" accounting requirements for not-for-profit organisations in America (compare, for example, FASB 1993 - SFAS 117), Canada (CICA 1996), the United Kingdom (Charity Commission 2000) and now Australia too (AASB 2005). From an analysis of these standards, it is clear that the fundamental aspects of these standards are the presentation of financial statements, the recognition of assets (and 
associated expenses), and the recognition of income of funds. It is notable that the abovementioned aspects attempt to address the fundamental problems experienced with the application of GAAP (as outlined briefly in what follows). According to Danyluk (1998:1-2), the Canadian standards deal specifically with accounting aspects which are unique to notfor-profit organisations, as well as other aspects of GAAP which are not relevant to these organisations.

\subsection{Legislation}

Although the standards of GAAP, for example, are not currently applicable in terms of the Preface to the IRFS to not-for-profit organisations (as outlined above), it is ironic that South African legislation indeed requires that not-for-profit organisations comply with GAAP. The Nonprofit Organisations Act (no. 71 of 1997, as amended by the Amendment Act, no. 17 of 2000) (RSA 1997), stipulates that organisations without a profit motive may choose to be registered as such in terms of the said Act (compare section 12 (1) and Kew et al. 2003:738). In terms of this Act, all registered not-for-profit organisations should "... to the standards of generally accepted accounting practice ... draw up financial statements ..." (compare section 17). The deduction is therefore made that the words "standards of generally accepted accounting practice" refer to SA GAAP, as issued by SAICA, discussed above. However, confusion may exist because the words in "generally accepted accounting practice" have been written in small letters, and the acronym generally refers to "gaap", which in terms of the arguments presented earlier, refers to general practice which has not been recorded in formal documents.

The irony is therefore that the Act does indeed require compliance, despite the fact that GAAP states clearly that these standards are not applicable to not-for-profit organisations. Nonetheless, the Act stipulates that the financial statements of a not-forprofit organisation may merely contain a report issued by an accounting officer (compare section 17(2)), and therefore does not have to be audited. Furthermore, the accounting officer's report is required to indicate, among other things, whether "... the accounting policies of the organisation are appropriate" and have been applied consistently when the financial statements were prepared (compare section $17(2)(b)$ ). Thus, it would appear that there is an anomaly in the Act, since the standards of GAAP are not applicable to not-forprofit organisations, but are nonetheless required. On the other hand, the Act implies that accounting policies can be followed which are "appropriate" to these organisations. This "applicable" and "appropriate" accounting policy will probably differ in certain cases from the standards of GAAP.

The nature of most welfare organisations is such that they are simply not in a position to comply with GAAP. Most organisations are rather small and operate on a cash basis. In any event, GAAP is "unsuitable" to these organisations as was indicated above (also compare Rossouw 2006:72). According to Kew et al. (2003:738), not-for-profit organisations that have not registered in terms of the Act have more flexibility in their financial accounting.

\subsection{Aspects relating to auditing}

Some aspects of Auditing are related to this aspect, and are discussed next. The focus of 
this research is on accounting aspects that pertain to not-for-profit organisations, and not to their auditing. An aspect in auditing which is related to the discussion of the relevance of GAAP is the concept of an "acceptable financial reporting framework". The management of an organisation is responsible for identifying and applying an "acceptable financial reporting framework" when financial statements are drawn up and presented. The auditor is then responsible for determining whether the financial reporting framework which management has applied is acceptable (compare IAASB 2004-ISA 700R: par. 28-29, 37 and Marx, Van der Watt, Bourne and Hamel 2004:1-5).

It was indicated above that not-for-profit organisations have a unique nature and characteristics, and for this reason, other (unique) accounting principles should be relevant. The International Auditing and Assurance Standards Board's (IAASB) Explanatory Memorandum, which deals with the proposed amendments that have bearing on the auditors' report (ISA 700 Revised), is consistent with these and determines that " $t \mathrm{t}]$ his guidance recognizes that applicable financial reporting frameworks differ depending on the nature of the entity (for example, profit-oriented, not-for-profit, government) and the objective of the financial statements ..." (IAASB 2003:5). Furthermore, the new international auditing standard stipulates that management must determine a relevant financial accounting framework which is suitable to the nature of the organisation, "...whether it is a business enterprise or a not-for-profit organization ..." (compare IAASB 2003:26). From this premise, we deduce that other possible accounting standards for notfor-profit organisations have already been considered by Auditing. A comprehensive discussion of the aspects of Auditing, however, is beyond the scope of this article.

It was indicated in the literature that Standards of GAAP were technically irrelevant in the case of not-for-profit organisations. GAAP applies primarily to businesses in international capital markets which have other reporting needs than not-for-profit organisations. GAAP is indeed irrelevant in the case of not-for-profit organisations because their nature and characteristics are different from the businesses for which GAAP has been drawn up. Unique accounting standards have already been or are being drawn up for specific industries in the business world (such as for the mining and the insurance industries), government institutions and SMEs to address their unique nature and accounting needs. Thus, the same approach should also be used in drawing up specific accounting standards for not-forprofit organisations.

To illustrate further the irrelevance of GAAP for not-for-profit organisations, some of the problems these organisations experience in applying GAAP are briefly outlined in the next section of this article.

\section{PROBLEMS POSED BY CURRENT GAAP FOR NOT-FOR-PROFIT ORGANISATIONS}

Where not-for-profit organisations do indeed attempt to apply Standards of GAAP, they nonetheless experience problems. This strongly indicates that GAAP is not applicable or relevant to these organisations. The discussion below does not pretend to be a comprehensive list of all problems, and only certain core problems are referred to very 
briefly. These problems are in addition to the problems that not-for-profit organizations, like SMEs, might experience because of their size - namely, the cost of applying IFRSs (GAAP) relative to the benefits thereof, and comprehending the complexity of IFRSs. Some of these problems derive from the theoretical irrelevance of the Standards of GAAP, as was indicated above, while other problems are of a more practical nature.

The fundamental problem derives from the question whether the cash or the accrual basis is the most appropriate in the case of not-for-profit organisations. In the accounting literature various arguments have been advanced for not-for-profit organisations following the cash basis of accounting for transactions (compare, for example, Cunningham and Reemsnyder in Jordan, Thompson and Malley 1991:58, Henke 1988:10, and Flynn and Koornhof 2005:chap.25 p.4-6). Moreover, "fund accounting" is typical of not-for-profit organizations. However, an accounting standard for treatment of "funds" does not exist. Fund accounting is not consistent with GAAP, and not-for-profit organisations experience various problems in the use of funds and reserves (compare Leo and Addison 2000(a):58). In spite of the conflict between "fund accounting" and GAAP, fund accounting may be considered appropriate for not-for-profit organisations and various guidelines have been issued in some countries (compare Rossouw 2006:206-215).

In addition, various problems are also experienced with the recognition of assets, impairments and depreciation of assets, because the definition of "assets" and the recognition criteria do not consider the unique nature of not-for-profit organisations. In terms of GAAP, an asset may only be recognised if future economic benefits are expected from that particular asset (IASB/SAICA 2006 - Framework: par. 49). Not-for-profit organisations often do not receive economic benefits from their assets, but rather utilise them to deliver goods or services for free (compare Granof 2001:6 and Rossouw 2006:8283), and these assets are often actually "cash-consumers" (Mautz 1994:15-16), which means that they do not meet the GAAP definition of an asset. Problems are also experienced in calculating the recoverable amount of assets for impairment tests, as these assets are not held to earn economic benefits (compare Rossouw 2006:83-84). Furthermore, various arguments have been raised for not calculating depreciation for the assets of not-forprofit organisations (compare, for example, Mautz 1994:67, 100-102, Flynne et al. 2000:chap.5 p.6, and Leo and Addison 2000(a):58).

Various questions have been raised with respect to the recognition of receipts as income. The question in particular is whether donations received for a specific purpose, donations which may only be utilised in future periods, as well as capital donations, should be recorded as income, liabilities or directly as funds. Not-for-profit organisations also experience problems with the recognition of so-called "in natura" receipts and other forms of income (compare Rossouw 2006:89-102). Given the nature and characteristics of notfor-profit organisations, performance reporting is also problematic because the "profit figure" and other reported financial information often do not capture the real "performance" (i.e. the achievement of objectives) of not-for-profit organisations. Furthermore, certain terminologies in GAAP are also not applicable to not-for-profit organisations. 


\section{CONCLUSION}

Standards of Generally Accepted Accounting Practice (GAAP) are drawn up primarily for businesses, and specifically to enable users of financial statements of companies in the international capital markets to take economic decisions. Given this fact, and the unique nature and characteristics of not-for-profit organisations, it follows that Standards of GAAP are neither relevant nor appropriate to not-for-profit organisations. Thus, the conclusion may be reached that the GAAP shoe does not fit not-for-profit organizations and the application of Standards of GAAP also does not add value to not-for-profit organisations. On the contrary, many problems are experienced by not-for-profit organisations in attempting to apply GAAP, and the metaphor of the GAAP shoe giving blisters to such organisations is therefore apt.

Standards of GAAP therefore cannot be applied indiscriminately to not-for-profit organisations, notwithstanding the fact that appropriate South African legislation (Nonprofit Organisations Act) probably requires compliance with Standards of GAAP. In the international accounting environment, attempts have been made to develop unique accounting standards for small- and medium-sized entities, while unique accounting standards have also been drawn up for government institutions on the basis of their unique accounting needs. The same approach should also be followed for not-for-profit organizations, since their unique nature and characteristics also necessitate appropriate accounting standards.

The core recommendations therefore are that existing and formal Standards of GAAP should be used as a basis for the process, and these standards should be modified to deal with the typical accounting concerns that pertain to not-for-profit organisations. The accounting profession, not-for-profit organisations, and other stakeholders must take note of the irrelevance of GAAP for not-for-profit organisations, the accounting problems experienced in the context, as well as the need for appropriate accounting standards for not-for-profit organisations. Like some other countries, South Africa should also play an active role in developing accounting standards which are applicable and relevant to not-for-profit organisations.

\section{REFERENCES}

AASB (Australian Accounting Standards Board). (2005). Accounting Standards. Available from: http://www.aasb.com.au/pronouncements/aasb_standards_2005.htm (Accessed 25 July 2005).

Archer, A. (2004). IFRS affects NFPs. CA Charter, 75(9), pp. 54-55.

ASB (Accounting Standards Board) (South Africa). (2004a). Generally Recognised Accounting Practice. Available from:

http://www.asb.co.za/backoffice/contentdocs/doc_18200411856_1l.pdf (Accessed 23 June 2005). 
ASB (Accounting Standards Board) (South Africa). (2004b). Generally Accepted Municipal Accounting Practice. Available from: http://www.asb.co.za/backoffice/contentdocs/doc_552004113559_11.pdf (Accessed 23 June 2005).

Cairns, D. (2001). International briefing. Accountancy, 128(1300), p. 87.

Cairns, D. (2002). Preface to IFRS. Accountancy, 129(1306), p. 114.

Charity Commission. (2000). SORP 2000 - Accounting and reporting by Charities: Statement of Recommended Practice (revised 2000). Available from: www.charity-commission.gov.uk/ publications/pdfs/sorptext.pdf (Accessed 6 January 2005).

CICA (The Canadian Institute of Chartered Accountants). (1996). 4400 series of the CICA Handbook. Available from: www.cica.ca (Accessed 26 July 2005).

Danyluk, K. (1998). Not-for-Profit Financial Reporting Guide. Toronto: The Canadian Institute of Chartered Accountants.

Durham, J. (1997). Interpreting nonprofit financial statements. Association Management, 49(1), p. 82.

Engstrom, J.H. \& Copley, P.A. (2004). Essentials of Accounting for Governmental and Not-forProfit Organizations. New York: McGraw-Hill/Irwin.

FASB (Financial Accounting Standards Board) (USA). (1993). Statement of Financial Accounting Standards No. 117-Financial Statements of Not-for-Profit Organizations. Available from: www.fasb.org/st/index.shtml (Accessed 21 April 2005).

Faul, M.A., Pistorius, C.W.I., Van Vuuren, L.M., Vorster, Q. \& Myburgh, J.E. (2004). Rekeningkunde'n Inleiding. Durban: LexisNexis Butterworths.

Flynn, D. \& Koornhof, C. (2005). Fundamental Accounting. Kenwyn: Juta \& Co.

Flynne S., Leo K. \& Addison P. (2000). Financial Reporting by Not-for-profit Entities, Melbourne:CPA Australia. Available from: http://www.cpaonline.com.au/cps/rde/xchg/SID-3F57FEDFIAC27FIE/cpa/hs.xsI/727_3067_ENA_HTML.htm (Accessed 14 January 2002).

Granof, M.H. (2001). Government and Not-for-Profit Accounting - Concepts and Practices. New York: John Wiley \& Sons, Inc.

Hattingh, C.P. (2001). Straight talking - The need for a second tier accounting system in South Africa. Accountancy SA, May 2001, pp. 35-37.

Henke, દ.0. (1988). Introduction to Nonprofit Organization Accounting. Boston: PWS-Kent Publishing Company.

Henke, દ.0. (1989). Accounting for Nonprofit Organizations. Boston: PWS-Kent Publishing Company.

IAASB (International Auditing and Assurance Standards Board). (2003). Exposure draftProposed Pronouncements on the Auditors' Report. New York: International Federation of Accountants (IFAC). 
IAASB (International Auditing and Assurance Standards Board). (2004). Internationa/ Standards on Auditing (ISA) 700 (Revised) - The Independent Auditor's Report on a Complete set of General Purpose Financial Statements. New York: International Federation of Accountants (IFAC).

IASB/SAICA (International Accounting Standards Board (IASB) \& The South African Institute of Chartered Accountants (SAICA)). (2006). Preface to International Financial Reporting Standards. London: International Accounting Standards Board.

IASB/SAICA (International Accounting Standards Board (IASB) \& The South African Institute of Chartered Accountants (SAICA)). (2006). Framework for the Preparation and Presentation of Financial Statements. London: International Accounting Standards Board.

Ives, M., Razek, J.R. \& Hosch, G.A. (2004). Introduction to Governmental and Not-for-Profit Accounting. Upper Saddle River: Pearson Prentice Hall.

Jordan, R.E., Thompson, J.H. \& Malley, J.C. (1991). Church Stewardship Evaluation Information Requirements: A Pilot Study. Public Budgeting \& Finance, 11(3), pp. 56-67.

Keegan, M. (2002). Truly, IASB's preface to IFRS needs tweaking. Accountancy, 129(1303), p. 17.

Kew, J., Mettler, C., Walker, T. \& Watson, A. (2003). Accounting an Introduction. Cape Town: Oxford University Press Southern Africa.

Kilcullen, L. (2005). Re: IFRS for not-for-profits. Email to: kilcullen@gsm.uwa.edu.na.

Larkin, R.F. \& DiTommaso, M. (2005). Wiley Not-for-Profit GAAP 2005 - Interpretations and Application of Generally Accepted Accounting Principles for Not-for-Profit Organizations. Hoboken: John Wiley \& Sons, Inc.

Lavigne, A. (1999). Standards with a difference. CA Magazine, 132(8), pp. 49-50.

Lee, S. \& Teixeira, A. (2004). Implications of IFRS for sector-neutral standard setting. Chartered Accountants Journal, 83(6), pp. 21-24.

Leo, K. \& Addison, P. (2000a). Help at hand for charities. Australian CPA, 70(7), pp. 56-58.

Leo, K. \& Addison, P. (2000b). No handouts for non-profits. Australian CPA, 70(8), pp. 52-53.

Lubbe, I. \& Watson, A. 2005. Accounting GAAP Principles. Cape Town: Department of Accounting, UCT (Oxford University Press).

Mautz, R.K. (1994). Financial Reporting for Nonprofit Organizations - A Fresh Look. New York and London: Garland Publishing, Inc.

Marx, B., Van der Watt, A., Bourne, P. \& Hamel A. (2004). Dinamiese Ouditkunde - 'n Studenteuitgawe. Durban: LexisNexis Butterworths.

Parker, C. (2003). Not-for-profits must take heed of IFRS. Australian CPA, 73(11), pp. 65-66.

Paterson, R. (2001). Widening the GAAP. Accountancy, 127(1293), p. 96.

Ponting, P. (1999). Standards failing not-for-profit organisations. Australian CPA, 69(9), p. 3.

Rossouw, J. (2006). Algemeen Aanvaarde Rekeningkundige Praktyk vir niewinsgewende organisasies, met verwysing na die NG Kerk in die Vrystaat. Unpublished Masters dissertation. Bloemfontein: University of the Free State. 
RSA (Republic of South Africa). (1997). Nonprofit Organisations Act (No. 71 of 1997 as amended by Nomprofit Organisations Amendment Act, No. 17 of 2000). Cape Town: Government Printer.

RSA (Republic of South Africa). (1998). GAMAP. Available from: www.info.gov.za/speeches/1998/98c48_gamap9811528.htm (Accessed 6 May 2005).

SAICA (South African Institute of Chartered Accountants). (1999). Circular 8/99: Compliance with section 286(3) and paragraph 5 of schedule 4 to the companies act, 61 of 1973 and statements of generally accepted accounting practice. Johannesburg: SAICA.

Sowden-Service, C. (2005). Gripping GAAP. Gillits:CSS Publishers.

Swilling, M. \& Russel, B. (2002). The size and scope of the non-profit sector in South Africa. Johannesburg en Durban: Graduate School of Public and Development Management, University of the Witwatersrand en The Centre of Civil Society, University of Natal.

Temkin, S. (2004). Nonprofit organisations lack accounting framework. Business Day 9 November 2004:2.

Vorster, Q., Koornhof, C., Oberholster, J.G.I. \& Koppeschaar, Z.R. (2004). Beskrywende Rekeningkunde. Durban: LexisNexisButterworths.

Wilson, E.R. \& Kattelus, S.C. (2004). Accounting for Governmental and Nonprofit Entities. New York: McGraw-Hill/Irwin. 
